\title{
Bud dormancy evolution in apple genotypes with contrasting chilling requirements
}

\author{
Rafael Anzanello ${ }^{1}$, Flávio Bello Fialho ${ }^{2}$, Henrique Pessoa dos Santos ${ }^{3}$ \\ Abstract - This work evaluates how thermal regimes with constant or oscillating temperatures \\ affect the onset and overcome of endodormancy in apple buds with low ('Castel Gala') and high \\ ('Royal Gala') chilling requirements. Apple twigs were collected in Papanduva-SC orchards \\ during the autumn/winter of 2010 and 2011 , and submitted to constant $\left(3^{\circ} \mathrm{C}\right)$ or cycling $\left(3 / 15^{\circ} \mathrm{C}\right.$ \\ for $6 / 18 \mathrm{~h}, 12 / 12 \mathrm{~h}$ or $18 / 6 \mathrm{~h}$ ) temperatures for up to 1466 chilling hours $(\mathrm{CH})$. Periodically, a portion \\ of twigs in each treatment was transferred to $25^{\circ} \mathrm{C}$, for budburst evaluation. An environmental \\ stress in 2010 caused premature leaf fall on the field, reduced initial budburst in 'Royal Gala' \\ samples and interfered with dormancy onset in both cultivars. Cycling temperature treatments \\ with few $\mathrm{CH} /$ day decreased partially this effect, allowing buds to enter a dormancy state more \\ efficiently. No significant stress was observed in the orchard in 2011, when dormancy evolution \\ was similar in all thermal treatments, being induced with 54 and $123 \mathrm{CH}$ and overcome with 363 \\ and $662 \mathrm{CH}$ for 'Castel Gala' and 'Royal Gala', respectively. Apparently, the manner in which \\ apple bud dormancy is induced affects its depth and consequently the total number of chilling \\ hours required to overcome it, making the onset phase fundamental in dormancy studies. \\ Index terms: cold, endodormancy, budburst, modeling, Malus domestica.

\section{Evolução da dormência de gemas em genótipos de macieira contrastantes em necessidade de frio}

\begin{abstract}
Corresponding author:
rafael-anzanello@agricultura.rs.gov.br

Received: November 11, 2021

Accepted: February 10, 2022

Copyright: All the contents of this journal, except where otherwise noted, is licensed under a Creative Commons Attribution License.

\section{(cc) E'}

\begin{abstract}
Resumo - Avaliou-se o efeito de regimes térmicos com temperaturas constantes e oscilantes na indução e na superação da endodormência de gemas de macieiras com baixa ('Castel Gala') e alta ('Royal Gala') necessidade de frio. Estacas de macieiras foram coletadas em pomares em Papanduva-SC, no outono/inverno de 2010 e 2011, e submetidas a temperaturas constante $\left(3^{\circ} \mathrm{C}\right)$ ou alternadas $\left(3 / 15^{\circ} \mathrm{C}\right.$ por $6 / 18 \mathrm{~h}, 12 / 12 \mathrm{~h}$ ou $\left.18 / 6 \mathrm{~h}\right)$ por até 1.466 horas de frio (HF). Periodicamente, parte das estacas de cada tratamento foi transferida para $25^{\circ} \mathrm{C}$, para a avaliação da brotação. Um estresse ambiental em 2010 causou queda prematura das folhas no campo, reduziu a brotação inicial em 'Royal Gala' e interferiu na indução da dormência em ambas as cultivares. Tratamentos com temperaturas alternadas com poucas $\mathrm{HF}$ /dia diminuíram parcialmente este efeito, permitindo que as gemas entrassem em estado de dormência mais eficientemente. Nenhum estresse foi observado no pomar em 2011, quando a evolução da dormência foi similar entre os tratamentos térmicos, sendo induzida com 54 e 123 HF e superada com 363 e 662 HF para 'Castel Gala' e 'Royal Gala', respectivamente. Aparentemente, a entrada da dormência em macieira afeta a profundidade e o número total de HF necessários para superá-la, tornando esta etapa fundamental em estudos de dormência.
\end{abstract}

Termos para indexação: frio, endodormência, brotação, modelagem, Malus domestica.

${ }^{1}$ Dr in Plant Science, Researcher, Departmento de Diagnóstico e Pesquisa Agropecuária, Secretaria da Agricultura, Pecuária e Desenvolvimento Rural, Veranópolis-RS, Brazil. Email: rafael-anzanello@agricultura.rs.gov.br (ORCID 0000-0002-2406-2789)

${ }^{2} \mathrm{Ph} . \mathrm{D}$ in Agricultural and Biological Engineering, Researcher, Embrapa Uva e Vinho, Bento Gonçalves-RS, Brazil. Email: flavio.bello@ embrapa.br (ORCID 0000-0001-8568-2204)

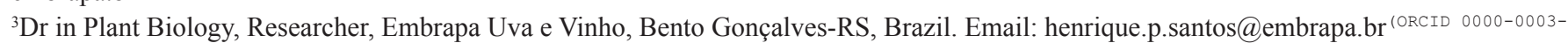
4066-1463) 


\section{Introduction}

Apples and other fruit species may undergo dormancy, a period of temporary suspension of visible growth of plant tissue (HAWERROTH et al., 2010). Bud dormancy may occur in three forms: paradormancy, endodormancy and ecodormancy (LANG et al., 1987). Paradormancy is the inhibition of bud growth by influence of another organ of the plant (e.g. apical dominance). Ecodormancy is caused by a temporary environmental restriction, such as water stress or lack of high temperatures. Endodormancy occurs during colder months, when bud development is hindered by biochemical and physiological events in the meristem or nearby regions, triggered by environmental stimuli, such as low temperatures or changes in photoperiod. Once triggered, endodormancy will remain in effect until a certain number of chilling hours $\left(\mathrm{CH}\right.$, sum of hours with air temperature $\leq 7.2^{\circ} \mathrm{C}$; WEINBERGER, 1950) is reached. Meeting chilling requirements is essential to avoid phenological disorders, such as insufficient or nonuniform budbreak and flowering (ALLDERMANN et al., 2011; ATKINSON et al., 2013; MALAGI et al., 2015; DIGGLE; MULDER, 2019). Although the exact biochemical mechanisms controlling endodormancy are still not totally known (LEMPE et al., 2022), chilling requirements vary among species and cultivars (KRETZSCHMAR et al., 2011; ANZANELLO et al., 2014a, LONDO; JOHNSON, 2014; FADÓN et al., 2020).

The apple producing region in the south of Brazil is marginal in cold availability, with an average of 211 to $867 \mathrm{CH}$, depending on the location (PETRI et al., 2019). Large variations occur from one year to another, with a frequent occurrence of insufficient yearly number of $\mathrm{CH}$ to overcome dormancy. The situation tends to worsen with climate changes, which tend to increase temperature and drastically reduce the number of $\mathrm{CH}$ in this region (CARDOSO et al., 2012; IPCC, 2015).

Most cycles require practices to overcome dormancy and induce budbreak, usually by chemical spraying (IONESCU et al., Moller; 2017). Some dormancy breaking compounds, such as hydrogen cyanamide, are highly toxic to humans and the environment, leading them to be prohibited in many countries (EFSA, 2010). Nevertheless, hydrogen cyanamide is very effective in inducing budbreak, and is still recommended in Brazil to compensate for variations in yearly $\mathrm{CH}$. Understanding bud response to local thermal conditions could lead to better management and avoiding unnecessary spraying of toxic products.

Models to quantify chill and its effect on dormancy and budbreak of deciduous fruit trees have been used since the 1930s (LUEDELING; BROWN, 2011). Most are based on old studies, like chilling hours below $7.2^{\circ} \mathrm{C}$ (WEINBERGER, 1950), the Utah model (Richardson;
Seeley; Walker, 1974) and the North Carolina model (SHALTOUT; UNRATH, 1983). Although these models are used in Brazil, they are based on dormancy experiments conducted with different genotypes and climatic conditions, having been adjusted mainly for peaches in North America, where autumn and winter temperatures are regularly low (WEINBERGER, 1950; RICHARDSON et al., 1974). However, for apple production in southern Brazil, where large temperature fluctuations occur, these models are less reliable and accurate (FELIPPETO et al., 2013). Dormancy in cultivars of different chilling requirements should be studied in more detail under these conditions, in order to adjust or develop dormancy models useful for southern Brazil. This work evaluates how thermal regimes with constant or oscillating temperatures affect the onset and overcome of endodormancy in apple buds with contrasting chilling requirements.

\section{Materials and methods}

Dormancy was evaluated in twigs of two apple cultivars with high ('Royal Gala') and low ('Castel Gala') chilling requirements (DENARDI; SECCON, 2005; PETRI et al., 2021). Twigs with about 20-25 cm length were sampled from a commercial orchard in Papanduva, SC (26 26'68'S, 50 $05^{\circ} 47^{\prime}$ 'W, 788m), in April, May and June 2010, and April 2011. Field CH were calculated for each sampling date using meteorological data from a National Institute of Meteorology (INMET) automatic station in Major Vieira, SC, $18 \mathrm{~km}$ from the orchard. Collected material was selected based on bud maturity (fully closed), health, and terminal bud diameter $(\sim 5 \mathrm{~mm})$. Twigs with any remaining leaves removed were wrapped in moist newspaper inside plastic bags and transported on the same day to Embrapa Uva e Vinho, Bento Gonçalves, $\mathrm{RS}$, for processing and dormancy evaluation.

Twigs were cut $20 \mathrm{~cm}$ below the apical bud, retaining approximately 6-10 lateral buds, cleaned with $70 \%$ ethanol for $45-60 \mathrm{~s}$ and $2.5 \%$ sodium hypochlorite for $20 \mathrm{~min}$, rinsed three times with distilled water and shade dried for $30 \mathrm{~min}$. Groups of 20 twigs were packed in black plastic film, set upright inside Eletrolab EL202 incubator chambers set to different thermal regimes. In 2010 , temperature was constant $\left(3^{\circ} \mathrm{C}, 24 \mathrm{CH} / \mathrm{d}\right)$ or cycled between 3 and $15^{\circ} \mathrm{C}$ for $6 / 18 \mathrm{~h}(6 \mathrm{CH} / \mathrm{d}), 12 / 12 \mathrm{~h}(12 \mathrm{CH} / \mathrm{d})$ or $18 / 6 \mathrm{~h}(18 \mathrm{CH} / \mathrm{d})$, which resemble temperatures of the main apple producing region of southern Brazil during the winter period, mainly in Vacaria/RS, Fraiburgo/SC and São Joaquim/SC. In 2011, thermal regimes were constant $\left(3^{\circ} \mathrm{C}, 24 \mathrm{CH} / \mathrm{d}\right)$, daily $12 / 12 \mathrm{~h}$ cycles of $3 / 15^{\circ} \mathrm{C}(12 \mathrm{CH} / \mathrm{d})$, or a mixed treatment consisting of cycling temperatures $\left(12 / 12 \mathrm{~h}, 3 / 15^{\circ} \mathrm{C}\right)$ for the first $72 \mathrm{CH}$, followed by constant $\left(3^{\circ} \mathrm{C}\right)$ from 72 to $264 \mathrm{CH}$, and cycling again after $264 \mathrm{CH}$ (Mixed). 
Thermal regimes were applied until $\mathrm{CH}$ reached a total (including field $\mathrm{CH}$ ) of up to 782 for 'Castel Gala' and 1466 for 'Royal Gala'. Periodically, two groups of 20 twigs per combination of cultivar and thermal regime were transferred to a Percival Boone 50036 plant growth chamber set to $25 \pm 1.5^{\circ} \mathrm{C}, 70-80 \%$ humidity and $12 \mathrm{~h}$ photoperiod. Twigs had the bottom tip cut off to unblock vascular bundles, and were disposed upright in water (2010) or moistened phenolic foam (2011), according to the methods described by Anzanello et al. (2014b). The use of phenolic foam in 2011 was an improvement in the methodology, designed to increase the longevity of twigs in the growth chamber. Control treatments consisted of two groups of 40 twigs per cultivar and sampling date, transferred to the growth chamber immediately after sampling (with only field $\mathrm{CH}$ ).

Apical budburst in the growth chamber was recorded daily, for up to 35 days, as the date when the green tip stage was reached (CARVALHO et al., 2010). In each group of 20 twigs (or 40 in the control treatments), budburst dates were used to calculate maximum budburst ( $M$, sprouted twigs divided by total twigs, \%), which was expressed as a function of the number of chilling hours and modeled as double sigmoids (FIALHO et al., 2020). Lateral buds were not considered in the evaluation, because they are mainly controlled by paradormancy (apical dominance) in apple branches (ANZANELLO et al., 2014b). The number of $\mathrm{CH}$ required for dormancy induction was calculated numerically at the point where budburst reduction reached $95 \%$ of the total decrease, in order to increase robustness of the estimates. Similarly, $\mathrm{CH}$ requirements to overcome dormancy were calculated at the point where budburst increase reached $90 \%$ of the difference between the minimum and asymptotic maximum levels (FIALHO et al., 2020). In order to compare all data simultaneously (and not only individual points), the resulting curves of each treatment were compared using a hierarchical F-test, testing them against a single curve including multiple treatments, using the R software (R DEVELOPMENT CORE TEAM, 2022).

\section{Results and discussion}

The initial physiological condition of buds on each sample date is shown on Figure 1, in which budburst follows an asymmetrical sigmoid function of time, modeled by the Gompertz curve (FIALHO et al., 2020). There were clear differences between cultivars and among sampling dates, which resulted in contrasting maximum budburst rates at 35 days in the growth chamber, represented by the rightmost point of the graphs in Figure 1 and the leftmost point on each graph in Figures 2, 3 and 4. The number of field $\mathrm{CH}$ in 2010 was 2, 15 and 80 in April, May and June, respectively, and is included in the total, which accounts for the difference in the starting points on the $\mathrm{x}$-scale in the last three figures.
2010

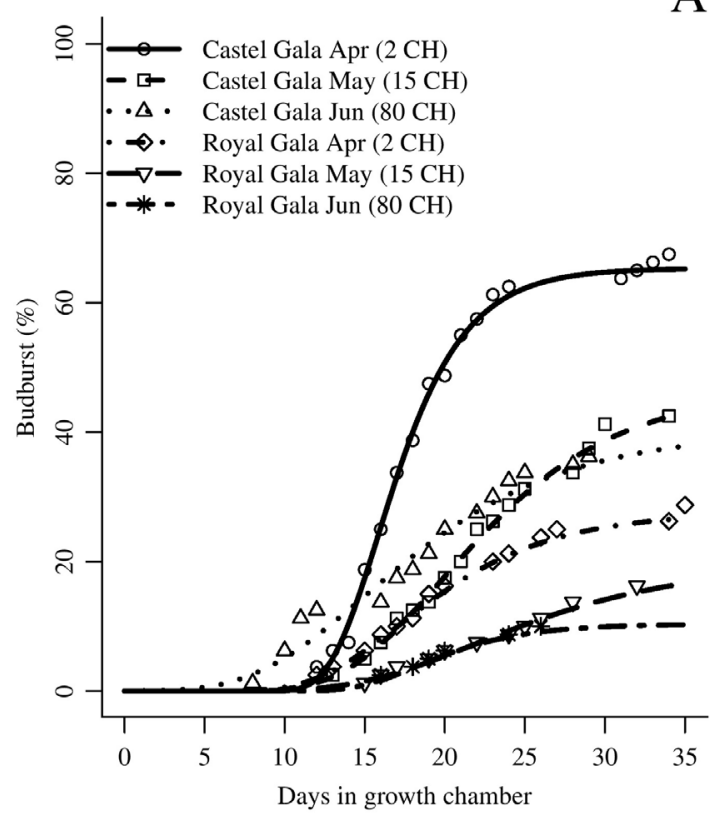

A

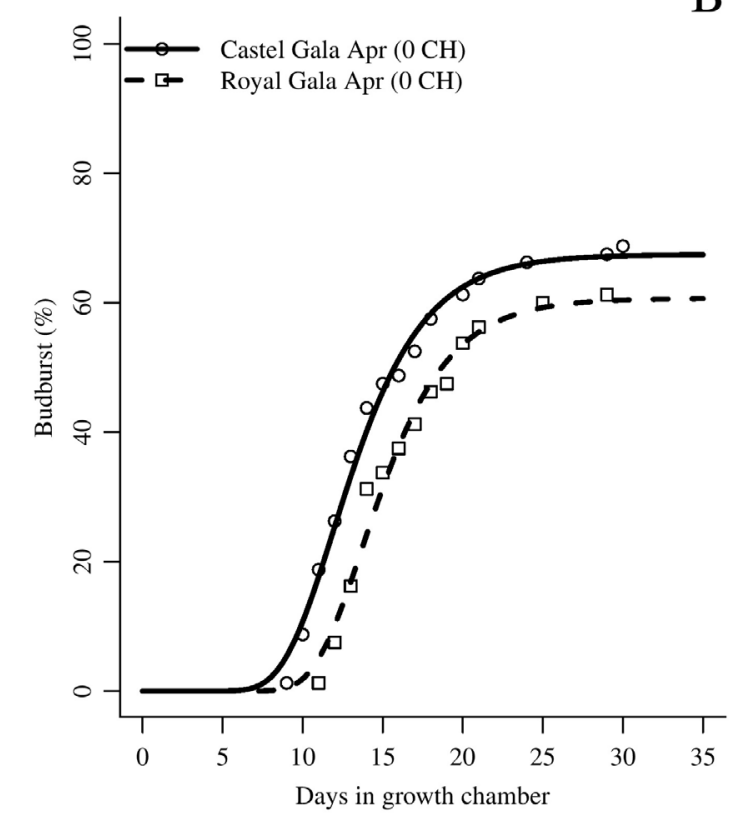

Figure 1 - Evolution of budburst of 'Castel Gala' and 'Royal Gala' apical buds with no artificial chilling treatment (control buds). Buds were sampled in April, May and June 2010 (A) or April 2011 (B), with only natural chilling hours, and submitted to $25^{\circ} \mathrm{C}$ for 35 days in a growth chamber. 


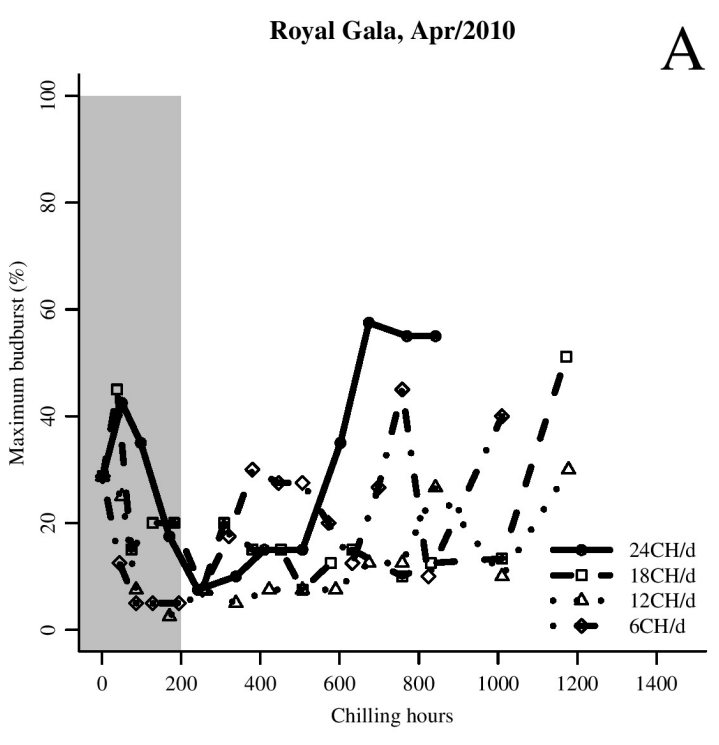

Royal Gala, May/2010
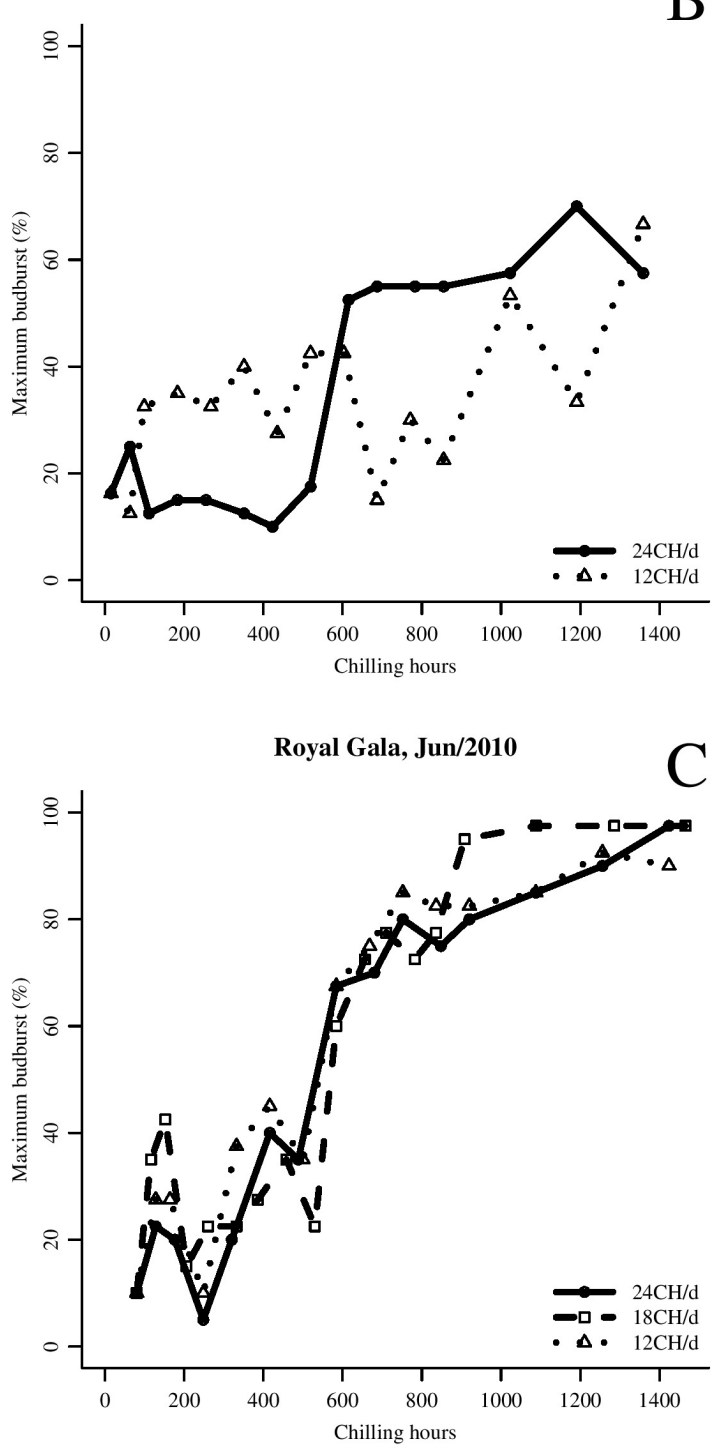

$\mathrm{R}^{2}$ (single curve) $=0.230$

$\mathrm{R}^{2}$ (data fit) $=0.709$

$\mathrm{R}^{2}$ (model fit) $=0.861$

$\mathrm{Y}=30.61-\frac{16.41}{1+\mathrm{e}^{-0.231 \cdot(\mathrm{X}-63.88)}}+\frac{15.71}{1+\mathrm{e}^{-0.231 \cdot(\mathrm{X}-648.8)}}$

$\mathrm{CV}=49.3 \%$

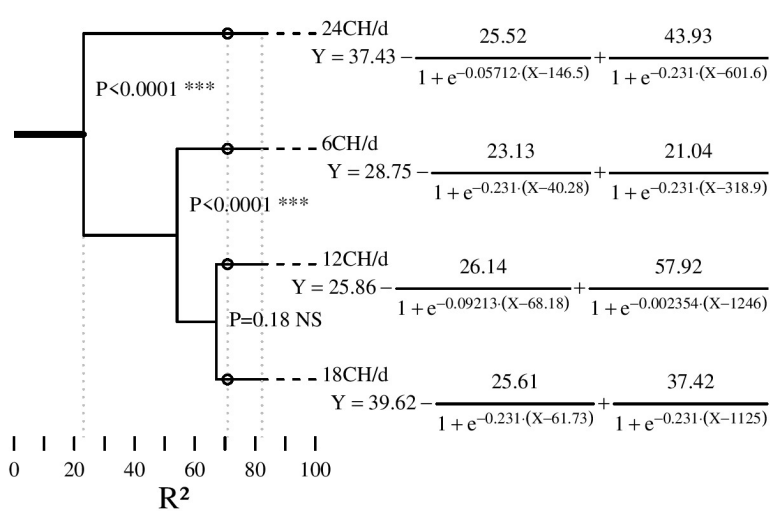

$\mathrm{R}^{2}$ (single curve $)=0.492$

$\mathrm{R}^{2}$ (data fit) $=0.737$

$\mathrm{R}^{2}$ (model fit) $=0.799$

$\mathrm{CV}=30.7 \%$
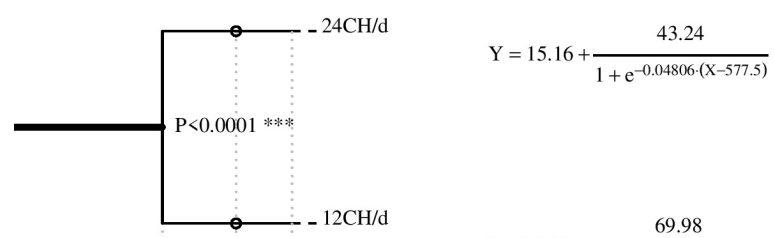

\begin{tabular}{ccccccccccc} 
I & I & I & I & I & I & I & I & I & I & I \\
0 & & 20 & & 40 & 60 & 80 & 100 \\
& & & & \multicolumn{2}{c}{$\mathrm{R}^{2}$} & & & &
\end{tabular}

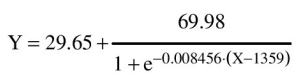

$\mathrm{R}^{2}$ (single curve) $=0.890$

$\mathrm{R}^{2}$ (data fit) $=0.905$

$\mathrm{R}^{2}$ (model fit) $=0.930$

$\mathrm{Y}=19.67+\frac{70.88}{1+\mathrm{e}^{-0.009636 \cdot(\mathrm{X}-576.7)}}$

$\mathrm{CV}=18.1 \%$
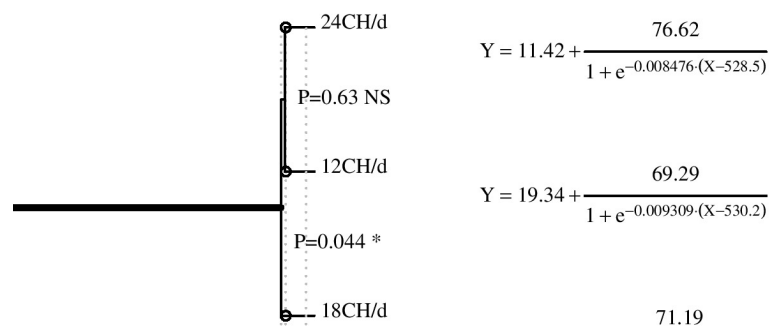

$\mathrm{Y}=19.34+\frac{69.29}{1+\mathrm{e}^{-0.009309 \cdot(\mathrm{X}-530.2)}}$

$\begin{array}{lllllllllll}1 & 1 & 1 & 1 & 1 & 1 & 1 & 1 & 1 & 1 & 1\end{array}$

$\mathrm{Y}=23.97+\frac{71.19}{1+\mathrm{e}^{-0.01093 \cdot(\mathrm{X}-636.4)}}$

Figure 2 - Budburst of 'Royal Gala', sampled in April (A), May (B) and June (C) 2010 with 2, 15 and $80 \mathrm{CH}$ in the field, and submitted in a growth chamber to $3^{\circ} \mathrm{C}$ or daily cycles of $18 / 6 \mathrm{~h}, 12 / 12 \mathrm{~h}$ or $6 / 18 \mathrm{~h}$ at $3^{\circ} \mathrm{C}$ and $15^{\circ} \mathrm{C}$ during dormancy. The shaded area corresponds to the dormancy induction period. A graphical representation of the analysis of variance is shown at the right. 


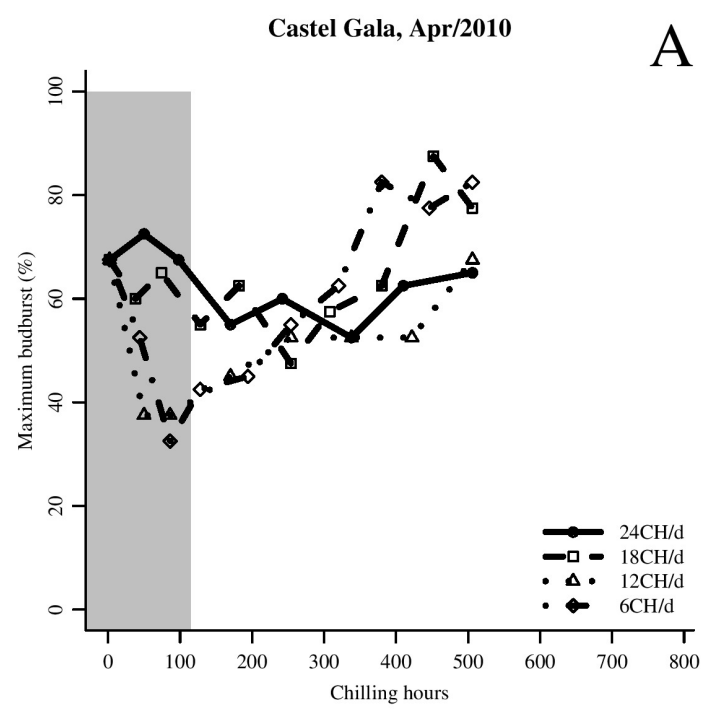

A

$\begin{aligned} & \mathrm{R}^{2} \text { (single curve) }=0.337 \\ & \mathrm{R}^{2} \text { (data fit) }=0.683 \\ & \mathrm{R}^{2} \text { (model fit) }=0.899\end{aligned} \quad \mathrm{Y}=68.48-\frac{17.83}{1+\mathrm{e}^{-0.08772 \cdot(\mathrm{X}-34.56)}}+\frac{25.47}{1+\mathrm{e}^{-0.02078 \cdot(\mathrm{X}-369)}}$

$\mathrm{CV}=17.5 \%$

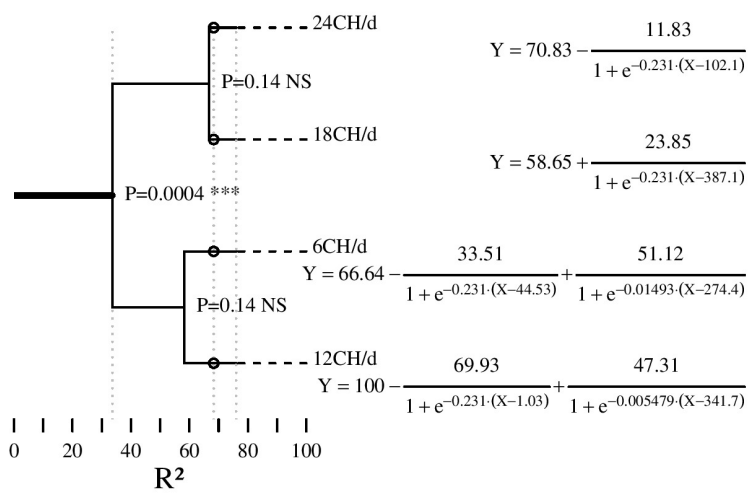

Castel Gala, May/2010

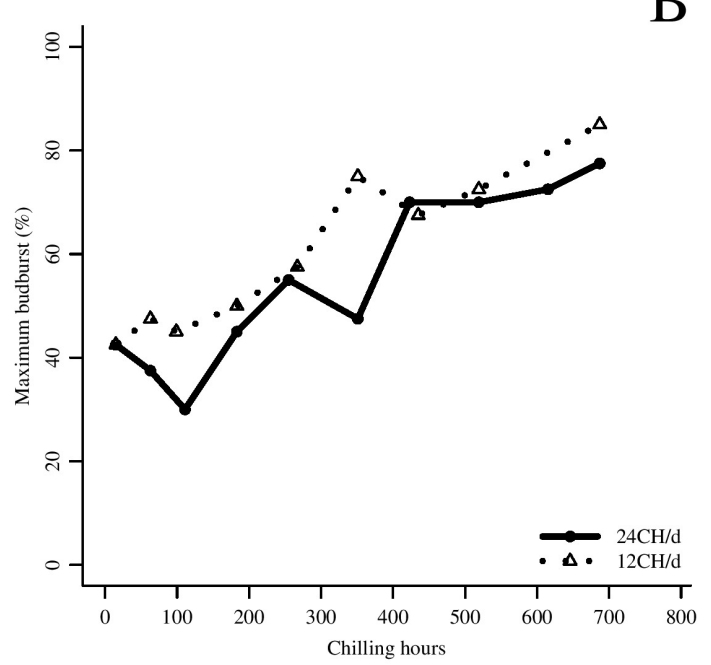

Castel Gala, Jun/2010

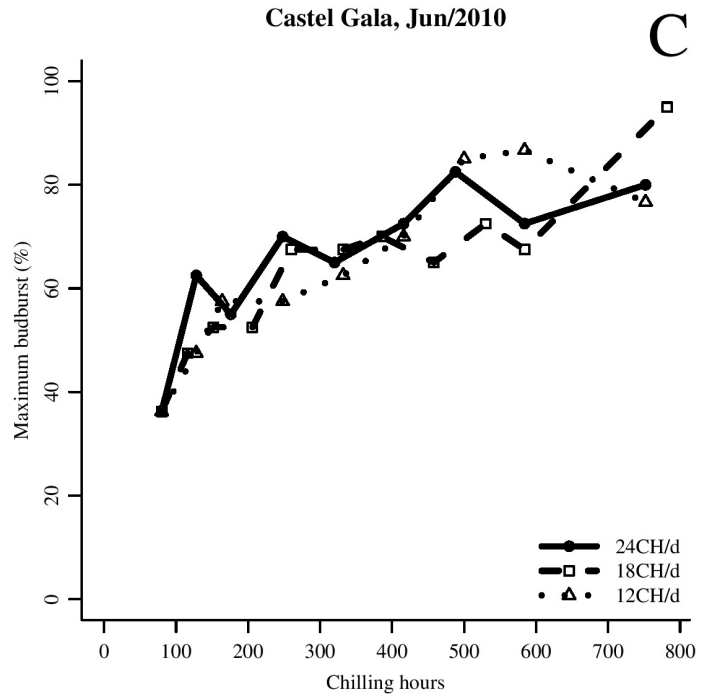

$R^{2}$ (single curve) $=0.694$

$\mathrm{R}^{2}$ (data fit) $=0.746$

$\mathrm{R}^{2}$ (model fit) $=0.899$

$\mathrm{CV}=16.8 \%$

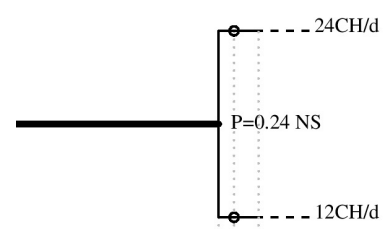

$\mathrm{Y}=35.68+\frac{41.87}{1+\mathrm{e}^{-0.00967 \cdot(\mathrm{X}-348.6)}}$

$\mathrm{Y}=25.47+\frac{66.45}{1+\mathrm{e}^{-0.004471 \cdot(\mathrm{X}-259.6)}}$

$\begin{array}{lllllllllll}\text { I } & \text { I } & \text { I } & \text { I } & \text { I } & \text { I } & \text { I } & \text { I } & \text { I } & \text { I } & \text { I } \\ 0 & 20 & 40 & 60 & 80 & 100\end{array}$

$\mathrm{R}^{2}$

$\mathrm{R}^{2}$ (single curve) $=0.583$

$\mathrm{R}^{2}$ (data fit) $=0.612$

$\mathrm{R}^{2}$ (model fit) $=0.825$

$\mathrm{CV}=17.6 \%$
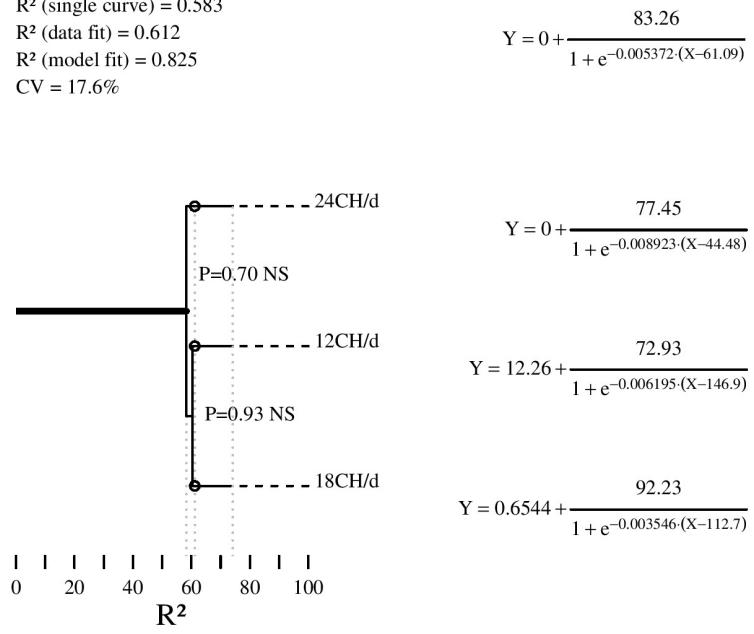

$\mathrm{Y}=0.6544+\frac{92.23}{1+\mathrm{e}^{-0.003546 \cdot(\mathrm{X}-112.7)}}$

Figure 3 - Budburst of 'Castel Gala', sampled in April (A), May (B) and June (C) 2010 with 2, 15 and $80 \mathrm{CH}$ in the field, and submitted in a growth chamber to $3^{\circ} \mathrm{C}$ or daily cycles of $18 / 6 \mathrm{~h}, 12 / 12 \mathrm{~h}$ or $6 / 18 \mathrm{~h}$ at $3^{\circ} \mathrm{C}$ and $15^{\circ} \mathrm{C}$ during dormancy. The shaded area corresponds to the dormancy induction period. A graphical representation of the analysis of variance is shown at the right. 


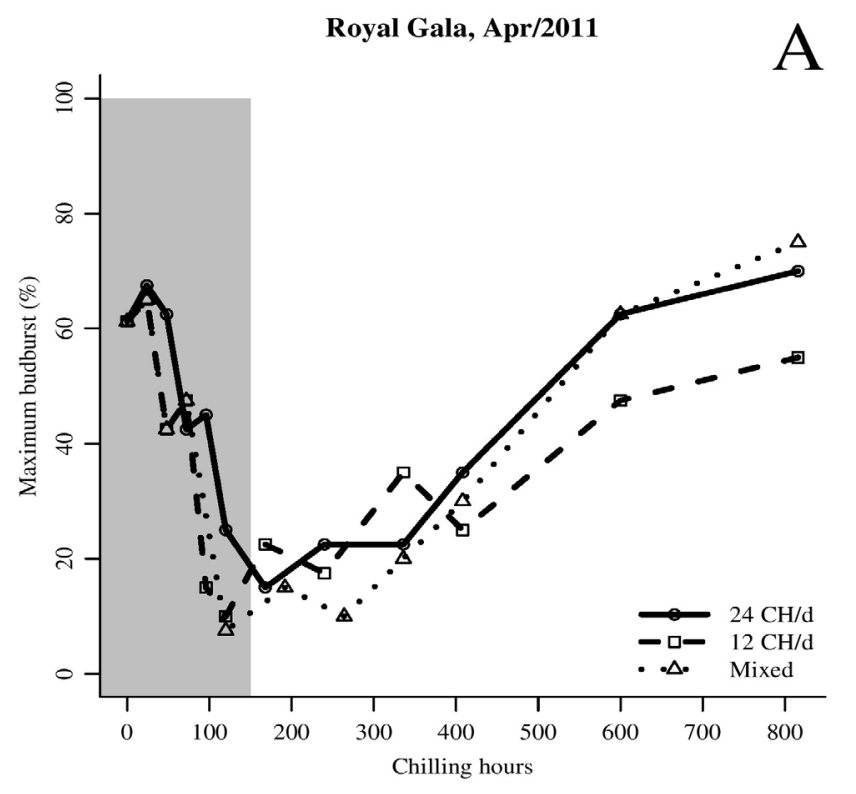

$$
\begin{aligned}
& \left.\mathrm{R}^{2} \text { (single curve }\right)=0.704 \\
& \mathrm{R}^{2} \text { (data fit) }=0.765 \\
& \left.\mathrm{R}^{2} \text { (model fit }\right)=0.948 \\
& \mathrm{CV}=35.7 \%
\end{aligned} \quad \mathrm{Y}=62.81-\frac{49.99}{1+\mathrm{e}^{-0.06055 \cdot(\mathrm{X}-79.33)}}+\frac{55.54}{1+\mathrm{e}^{-0.01056 \cdot(\mathrm{X}-471.9)}}
$$
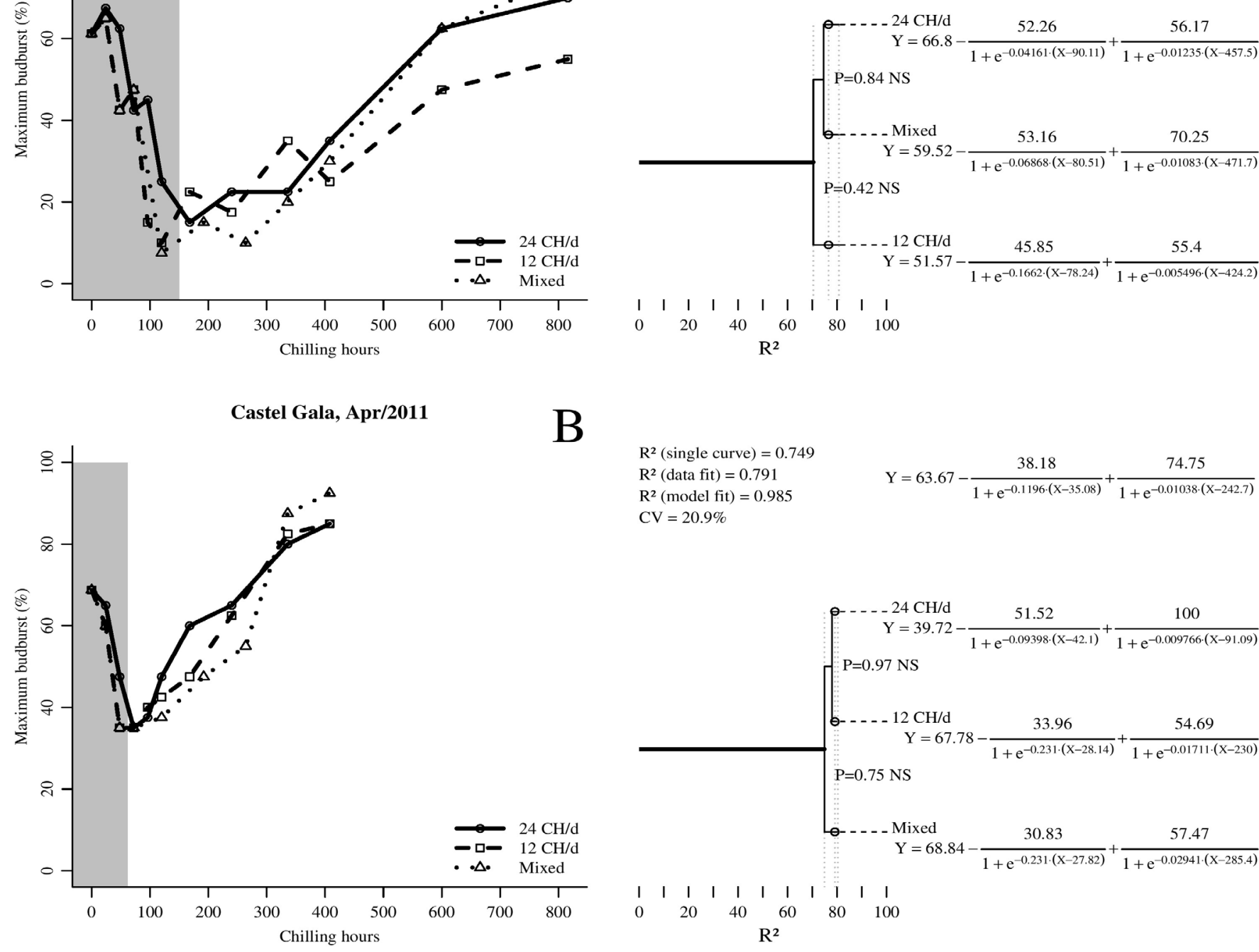

$$
\mathrm{Y}=63.67-\frac{38.18}{1+\mathrm{e}^{-0.1196 \cdot(\mathrm{X}-35.08)}}+\frac{74.75}{1+\mathrm{e}^{-0.01038 \cdot(\mathrm{X}-242.7)}}
$$

$\mathrm{R}^{2}$ (model fit) $=0.98$ $\mathrm{CV}=20.9 \%$

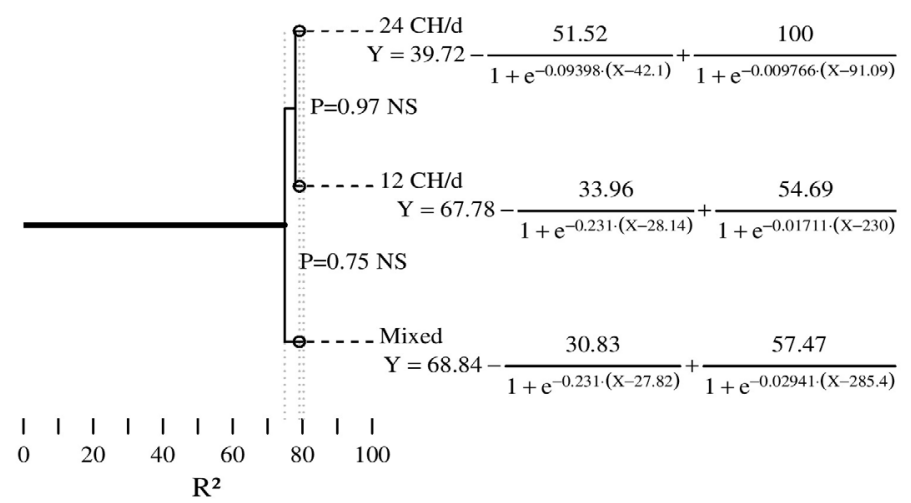

Figure 4 - Budburst of 'Royal Gala' (A) and 'Castel Gala' (B), sampled in April 2011 and submitted in a growth chamber a to $3^{\circ} \mathrm{C}(24 \mathrm{CH} / \mathrm{d})$, daily $12 / 12 \mathrm{~h}$ cycles of $3 / 15^{\circ} \mathrm{C}(12 \mathrm{CH} / \mathrm{d})$ or cycling $\left(12 / 12 \mathrm{~h}, 3 / 15^{\circ} \mathrm{C}\right)$ for $72 \mathrm{CH}+$ constant $\left(3^{\circ} \mathrm{C}\right.$ ) from 72 to $264 \mathrm{CH}+$ cycling after $264 \mathrm{CH}$ (Mixed), followed by 35 days in a growth chamber at $25^{\circ} \mathrm{C}$. The shaded area corresponds to the dormancy induction period. A graphical representation of the analysis of variance is shown at the right.

Dormancy induction in the field was verified by a reduction in maximum budburst in twigs which did not experience artificial chilling. This initial budburst potential decreased with time, during the months of 2010 (Figure 1A), in which an increase in the natural bud dormancy state occured. In 'Royal Gala', the greatest reduction in budburst potential occurred between April (29\%) and May (16\%), although it continued to decrease in June (10\%) (Figure 1A). The same pattern occurred in 'Castel Gala', in which budburst went from 68\% in April to $43 \%$ in May and $36 \%$ in June. By comparing minimum budburst values, it may be inferred that 'Royal Gala' reached a deeper state of dormancy than 'Castel Gala'.
According to Anzanello et al. (2014b), dormancy of apple cultivars can be classified as light, intermediate and deep, and this relates to chilling requirements. In light dormancy cultivars, such as 'Castel Gala', a superficial hindering of bud growth occurs, while deeper dormancy cultivars suffer near total bud growth paralysis. In addition, this hibernal behavior has been associated with growing cycle precociousness (CAMPOY et al., 2011a; EL YAACOUBI et al., 2016).

In order to further detail dormancy induction, 2011 samples were collected in April, before any field $\mathrm{CH}$ had occurred. Initial 'Castel Gala' budburst potential in 2011 (69\%) was similar to that of April 2010 (Figure 1). 
However, the smaller values observed in April 2010 'Royal Gala' samples were not repeated in April 2011, when initial budburst was $61 \%$, closer to that observed on 'Castel Gala'. Leaf fall occurred earlier in 2010 than in 2011, due to greater disease levels (apple leaf spot, caused by Colletotrichum spp.) observed in the field, due to heavier rainfall before the first sampling date $(659 \mathrm{~mm}$ in 2010 vs. $277 \mathrm{~mm}$ in 2011). These conditions may have anticipated leaf fall and induced dormancy prematurely in 2010, suggesting that the effect of cold on endodormancy induction may be influenced by other stress factors. Cooke et al. (2012) state that dormancy induction may also occur due to changes in photoperiod or as a result of biotic and abiotic stress in the field (e.g. pathogenic or water stress), not being solely dependent on temperature. Leaf fall in plants is related to increased ethylene and abscisic acid, synthesized in response to stressful factors and involved in dormancy induction (RUTTINK et al., 2007; COOKE et al., 2012). Garcia-Andrade et al. (2011) verified abscisic acid accumulation in Arabidopsis plants under fungal infection, with a consequent increase in callose deposition. Aloni et al. (1991) associate a presence of callose in vascular bundles of buds to the state of dormancy in Vitis vinifera grapevines. Another possibility is that the lower budburst rate was not caused by endodormancy, but by some metabolic restriction of meristem growth caused by stress, without activating dormancy-specific genes. Pathogenic stress by fungal diseases may influence the physiological responses of plants to abiotic factors (PRASCH; SONNEWALD, 2015; RAMEGOWDA; SENTHIL-KUMAR, 2015), changing the sensitivity of buds to temperature.

Dormancy was artificially induced on April samples in both years (Figures 2A, 3A and 4, shaded areas), and occurred naturally in the field on May and June samples. Treatments with cycling temperatures (6, 12 and $18 \mathrm{CH} / \mathrm{d}$ ) induced endodormancy in 'Royal Gala' more efficiently (with a smaller number of $\mathrm{CH}$ : 53, 98 and $74 \mathrm{CH}$, respectively) than the constant temperature ( $24 \mathrm{CH} / \mathrm{d}$ : $198 \mathrm{CH})$ treatment $(\mathrm{P}<0.0001)$. 'Castel Gala' endodormancy only occurred in treatments with 6 and $12 \mathrm{CH} / \mathrm{d}(\mathrm{P}=0.0004)$, reaching minimum budburst with 56 and $16 \mathrm{CH}$, respectively. Surprisingly, it was not induced at all by treatments with little or no daily mild temperatures $(18 \mathrm{CH} / \mathrm{d}$ and $24 \mathrm{CH} / \mathrm{d})$. It seems that the buds needed some time in warmer temperatures in order to process the chilling stimuli, especially in 'Castel Gala'. In peach trees, Couvillon and Erez (1985) showed that daily cycles of moderate and cold temperatures were more effective in inducing dormancy, compared to constantly cold conditions. The importance of alternating mild $\left(15^{\circ} \mathrm{C}\right)$ and cold $\left(3^{\circ} \mathrm{C}\right)$ temperatures in inducing dormancy was also observed in works with grapevines (ANZANELLO et al., 2018). Natural thermal conditions follow an oscillatory pattern, and the duration of daily cold increases as mean temperature decreases, with the progress of autumn. This explains why the best induction results were those of treatments with few $\mathrm{CH} / \mathrm{d}$, which follow conditions of natural dormancy induction. Furthermore, 'Castel Gala' bud meristem in April 2010 might not have fully matured to perceive cold stimulus, thus maintaining the same physiological state throughout the chilling period in treatments with few daily warm hours $(18$ and $24 \mathrm{CH} / \mathrm{d})$.

The effectiveness of cyclic $3 / 15^{\circ} \mathrm{C}$ regimes shows that just a few hours of daily cold suffice for endodormancy induction, in contrast to extremely low and constant temperatures. The benefit of oscillating temperatures in inducing endodormancy is also reported by Alldermann et al. (2011), who claim that low temperatures interspersed with mild autumn temperatures triggers the bud dormancy mechanism, causing changes in bud meristematic tissues which affect their cold resistance.

In 2011, no difference among treatments was detected in the dormancy evolution curves (Figure 4), even though the chilling period resolution was finer than 2010. Not only the F-tests were not significant $(P>0.10)$, but also the difference in $\mathrm{R}^{2}$ between the data fit using three curves and that of a single curve was very small ( 0.765 vs. 0.704 in 'Royal Gala'; 0.791 vs 0.749 in 'Castel Gala'). Therefore, all treatments within each cultivar were modeled by a single curve, represented by the general equations on Figures $4 \mathrm{~A}$ and $4 \mathrm{~B}$, which resulted in a requirement of 123 and $54 \mathrm{CH}$ for dormancy induction in 'Royal Gala' and 'Castel Gala', respectively. Considering only the cycling temperature treatments, induction requirements in 2011 (107 CH in 'Royal Gala' and $40 \mathrm{CH}$ in 'Castel Gala') were close to those of 2010 (75 CH in 'Royal Gala' and $36 \mathrm{CH}$ in 'Castel Gala'). The greatest contrast between years occurred when temperature was constant $(24 \mathrm{CH} / \mathrm{d})$ during the chilling period. In these conditions, the onset of dormancy in 2010 did not happened in 'Castel Gala' and was delayed in 'Royal Gala' by $123 \mathrm{CH}$ (when compared to the cycling temperature treatments), while in 2011 there was only a slight nonsignificant delay (22 CH in 'Castel Gala' and $44 \mathrm{CH}$ in 'Royal Gala'). This may also be associated to a smaller degree of stress in 2011, compared to the conditions of 2010. Anzanello et al. (2018) also verified no significant change in chilling requirements for dormancy induction, comparing two cycling regimes $\left(3\right.$ and $15^{\circ} \mathrm{C}$, for $18 / 6 \mathrm{~h}$ or $12 / 12 \mathrm{~h}$ ) and constant $3^{\circ} \mathrm{C}$ temperature, in 'Chardonnay', 'Merlot' and 'Cabernet Sauvignon' grapevine buds with no apparent stress in the field. 
The manner in which dormancy is induced may have an effect on its depth (minimum budburst) and on the amount of cold required to overcome it. Budburst in 2011 samples reached a minimum of $15 \%$ in 'Royal Gala' and 37\% in 'Castel Gala', considering the means of all treatments (Figure 4). As discussed previously, no significant effects of temperature cycle treatments were observed in 2011. This was also verified by Anzanello et al. (2014a), and is compatible with the models of Richardson et al. (1974) and Shaltout and Unrath et al. (1983), to whom moderate temperatures (around $15^{\circ} \mathrm{C}$ ) do not contribute or interfere with chilling accumulation. In Vitis vinifera grapevines, Anzanello et al. (2021) also found that dormancy evolution was not affected by daily cycling temperatures, with an $18^{\circ} \mathrm{C}$ temperature being inert for chilling accumulation.

Dormancy overcoming, considering the point where budburst recovered $90 \%$ of its potential increase, happened after a sum of $662 \mathrm{CH}$ in 'Royal Gala' and $363 \mathrm{CH}$ in 'Castel Gala', on average. These chilling requirements are close to those obtained by Denardi and Seccon (2005) for 'Castel Gala' (less than $400 \mathrm{CH}$ ) and Petri et al. (2021) for 'Royal Gala' (approximately $600 \mathrm{CH}$ ). The contrast in chilling requirements between genotypes is compatible with field observed phenology, in which 'Castel Gala', a natural mutation of 'Gala', flowers up to 25 days earlier (DENARDI; SECCON, 2005).

Considering dormancy evolution as a whole, it is possible to infer that the induction process is critical in determining total chilling requirements. With approximately twice the number of $\mathrm{CH}$, 'Royal Gala' reached a budburst level of nearly half the minimum observed in 'Castel Gala', characterizing a deeper state of dormancy. Likewise, its requirement to overcome dormancy was also nearly double that of 'Castel Gala', showing a relation between induction and total $\mathrm{CH}$. The mutation may have caused some of the induction steps to be absent, leading to a more superficial state of dormancy in 'Castel Gala' and, consequently, to a smaller chilling requirement. Anzanello et al. (2018) and Anzanello et al. (2021) also observed a direct relation between dormancy depth and total chilling requirement in grape cultivars.

In 'Royal Gala', significant differences occurred among treatments in most 2010 sampling dates (Figure 2). An erratic overcoming of dormancy occurred in the cycling temperature treatments in April and May, but not in June, when all treatments were similar $(\mathrm{P}>0.10)$. This behavior may have been caused by the stressful conditions which occurred in 2010 and restricted dormancy onset, as discussed previously. Although all buds suffered the same initial stress, those sampled in April and May had less time to recover than the June samples. Buds attached to the plant for a longer time eventually recovered from the environmental stress and, like in the April 2011 samples, all June 2010 treatments clearly overcame dormancy. As observed in this work, Lloyd and Firth (1990) noted that, in peach buds (cv. Flordaprince and Flordagold), stress caused by early defoliation interferes with dormancy evolution, altering the reserve accumulation process for the following crop and defining budburst potential.

The constant temperature treatment $(24 \mathrm{CH} / \mathrm{d})$ resulted in relatively uniform estimates of 'Royal Gala' chilling requirements $(611,623$ and $790 \mathrm{CH}$ in April, May and June 2010, respectively), which were similar to that observed in $2011(630 \mathrm{CH}$, with $24 \mathrm{CH} / \mathrm{d})$. The higher value observed in June was due to a continued, although small, increase in budburst after the steep rise which occurred around $600 \mathrm{CH}$ (Figure 2C). Furthermore, it resulted in greater maximum budburst after the 2010 dormancy period in June (88\%) than in April (56\%) and May (58\%), while the April 2011 samples resulted in an intermediate maximum budburst rate $(70 \%)$. It seems that whatever was hindering budburst and causing an erratic behavior in the cycling temperature treatments had its effect dampened when temperatures were constantly low.

In 'Castel Gala' 2010 samples, as in 'Royal Gala', stress conditions caused contrasting responses among treatments in the first couple of sampling dates (Figure 3). However, these responses did not follow the same pattern in both cultivars. As discussed previously, dormancy onset did not occur in April 2010 treatments with 18 and $24 \mathrm{CH} / \mathrm{d}$, in which average budburst remained above $58 \%$, regardless of the number of $\mathrm{CH}$. In treatments with 6 and $12 \mathrm{CH} / \mathrm{d}$, dormancy was both induced (reaching 36\%) and overcome, with budburst rate after about $250 \mathrm{CH}$ becoming similar to the other treatments. In May and June 2010 samples, where dormancy was naturally induced, no significant difference among treatments was observed. These buds, especially the June samples, as observed in 'Royal Gala', displayed similar responses to those of April 2011. The environmental stress response in both cultivars, stronger in the April 2010 samples, was dampened as buds remained attached to the plant for a longer period of time. However, some effect of stress still persisted until June, which made the 'Castel Gala' chilling requirement seem to be greater in $2010(551 \mathrm{CH})$ than the reference value estimated in $2011(363 \mathrm{CH})$, under normal growing conditions (DENARDI; SECCON, 2005).

This study only evaluated the effect of cycling moderate $\left(15^{\circ} \mathrm{C}\right)$ and cold $\left(3^{\circ} \mathrm{C}\right)$ temperatures on inducing and overcoming endodormancy, without analyzing ecodormancy. According to the dormancy evolution scheme in apple trees proposed by Faust et al. (1997), a dormant bud is initially in paradormancy, followed by an intermediate period of endodormancy, and a final stage of ecodormancy, with two transitions periods in which dormancy types overlap (paradormancyendodormancy and endodormancy-ecodormancy). In the last transition period, air temperature may be contributing simultaneously to chilling accumulation, for 
overcoming endodormancy, and to the sum of heat units, for overcoming ecodormancy (LUEDELING et al., 2013). Thus, winter temperatures may contribute simultaneously to chilling and heat requirements in different periods of dormancy, and should be considered together. In mild climate regions, chilling hours accumulate very slowly, leading to a prolonged endodormancy phase, which overlaps with ecodormancy (MALAGI et al., 2015). Campoy et al. (2011b) also observed that the chill and heat requirements for budburst induction are not subsequent processes and may occur simultaneously, which makes it difficult to identify precisely when to stop accumulating chill and start accumulating heat, for budbreak prediction. Molecular analysis of gene expression that regulates dormancy can be considered a valuable tool to indicate the transition from endodormancy to ecodormancy in apple trees (LEMPE et al., 2022). Additional studies are needed in order to further understand the effect of heat during the dormancy evolution and overcoming, throughout winter and early spring.

\section{Conclusions}

The chilling requirements to overcome dormancy are $662 \mathrm{CH}$ for 'Royal Gala' and $363 \mathrm{CH}$ for 'Castel Gala', while the requirements to induce dormancy are $123 \mathrm{CH}$ and $54 \mathrm{CH}$, respectively. Previous stressful environmental conditions restrict the onset of dormancy, its depth and the total number of chilling hours required to overcome it. Daily cycles of $3^{\circ} \mathrm{C}$ and $15^{\circ} \mathrm{C}$ do not affect chilling hours, relative to constantly cold temperatures $\left(3^{\circ} \mathrm{C}\right)$, but induce dormancy more efficiently, especially in environmental stress conditions.

\section{References}

ALLDERMANN, L.A.; STEYN, W.J.; COOK, N.C. Growth regulator manipulation of apple bud dormancy progressions under conditions of inadequate winter chilling. South African Journal of Plant and Soil, Pretoria, v.28, n.2, p.103-109, 2011.

ALONI, R.; RAVIV, A.; PETERSON, C.A. The role of auxin in the removal of dormancy callose and resumption of phloem activity in Vitis vinifera. Canadian Journal of Botany, Ottawa, v.69, n.8, p.1825-1832, 1991.

ANZANELLO, R.; FOGAÇA, C.M, SARTORI, G.B.D. Induction and overcoming of dormancy of grapevine buds in response to thermal variations in the winter period. Ciência Rural, Santa Maria, v.51, n.11, p.e20200887, 2021.
ANZANELlO, R.; FIALHO, F.B.; SANTOS, H.P. Chilling requirements and dormancy evolution in grapevine buds. Ciência e Agrotecnologia, Lavras, v.42, n.4, p.364-371, 2018.

ANZANELLO, R.; FIALHO, F.B.; SANTOS, H.P.; BERGAMASCHI, H.; MARODIN, G.A.B. Bud dormancy in apple trees after thermal fluctuations. Pesquisa Agropecuária Brasileira, Brasília, v.49, n.6, p.457-464, 2014a.

ANZANELLO, R.; FIALHO, F.B.; SANTOS, H.P.; BERGAMASCHI, H.; MARODIN, G.A.B. Métodos biológicos para avaliar a brotação de gemas em macieira para modelagem da dormência. Semina: Ciências Agrárias, Curitiba, v.35, n.3, p.1163-1176, 2014b.

ATKINSON, C.J., BRENNAN, R.M., JONES, H.G. Declining chilling and its impact on temperate perennial crops. Environmental and Experimental Botany, Oxford, v.91, p.48-62, 2013.

CAMPOY, J.A.; RUIZ, D.; EGEA, J. Dormancy in temperate fruit trees in a global warming context: a review. Scientia Horticulturae, Amsterdam, v.130, n.2, p.357372, 2011a.

CAMPOY, J.A.; RUIZ, D.; COOK, N.C.; ALLDERMAN, L. High temperatures and time to budbreak in low chill apricot 'Palsteyn'. Towards a better understanding of chill and heat requeriments fulfillment. Scientia Horticulturae, Amsterdam, v.129, n.4, p.649-655, 2011 b.

CARDOSO, L.S.; BERGAMASCHI, H. BOSCO, L.C.; PAULA, V.A.; MARODIN, G.A.B; CASAMALI, B.; NACHTIGALL, G.R. Disponibilidades climáticas para macieira na região de Vacaria, RS. Ciência Rural, Santa Maria, v.42, n.11, p.1960-1967, 2012.

CARVALHO, R.I.N.; BIASI, L.A.; ZANETTE, F.; SANTOS, J.M.; PEREIRA, G.P. Estádios de brotação de gemas de fruteiras de clima temperado para o teste biológico de avaliação de dormência. Revista Acadêmica de Ciências Agrárias e Ambientais, Curitiba, v.8, n.1, p.93-100, 2010.

COOKE, J.E.K.; ERIKSSON, M.E.; JUNTTILA, O. The dynamic nature of bud dormancy in trees: environmental control and molecular mechanisms. Pant, Cell and Environmet, Oxford, v.35, n.10, p.1707-1728, 2012.

COUVILLON, G.A.; EREZ, A. Effect of level and duration of high-temperatures on rest in the peach. Journal of the American Society for Horticultural Science, Mount Vernon, v.110, n.4, p.579-581, 1985. 
DENARDI, F.; SECCON, J. J. 'Castel Gala' - mutação da macieira 'Gala' com baixa necessidade de frio e maturação precoce. Revista Agropecuária Catarinense, Florianópolis, v.18, n.2, p.78-82, 2005.

DIGGLE, P.K.; MULDER, C.P.H. Diverse developmental responses to warming temperatures underlie changes in flowering phenologies. Integrative and Comparative Biology, Oxford, v.59, n.3, p.559-570, 2019.

EFSA - European Food Safety Authority. Conclusion on the peer review of the pesticide risk assessment of the active substance cyanamide. EFSA Journal, Parma, v.8, n.11, p.1-61, 2010.

EL YAACOUBI, A.; MALAGI G.; OUKABLI A.; CITADIN I.; HAFIDI M.; BONHOMME M.; LEGAVE J.M. Differentiated dynamics of bud dormancy and grow thin temperate fruit trees relating to bud phenology adaptation, the case of apple and almond trees. International Journal of Biometeorology, Lisse, v.60, n.11, p.1695-1710, 2016.

FADÓN, E.; HERRERA, S.; GUERRERO, B.I.; GUERRA, M.E.; RODRIGO, J. Chilling and heat requirements of temperate stone fruit trees (Prunus sp.). Agronomy, Basel, v.10, n.3, p.1-32, 2020.

FAUST, M.; EREZ, A.; RAWLAND, L.J.; WANG, S.Y.; NORMAN, H. Bud dormancy in perennial fruit trees: physiology basis for dormancy induction, maintenance, and release. HortScience, Alexandria, v.32, n.4, p.623$629,1997$.

FELIPPETO, J.; BERGONCI, J.I.; SANTOS, H.P.; NAVA, G. Modelos de previsão de brotação para a cultivar de videira Cabernet Sauvignon $\mathrm{Na}$ Serra Gaúcha. Agropecuária Catarinense, Florianópolis, v.26, n.1, p.85-91, 2013.

FIALHO, F. B.; SANTOS, H. P.; ANZANELLO, R. Modelo matemático para avaliação da dormência em gemas de plantas frutíferas de clima temperado. Bento Gonçalves: Embrapa Uva e Vinho, 2020. 25 p. (Circular Técnica, 151).

GARCÍA-ANDRADE, J.; RAMÍREZ, V.R.; FLORS, V.; VERA, P. Arabidopsis ocp3 mutant reveals a mechanism linking ABA and JA to pathogen-induced callose deposition. Plant Journal, Oxford, v.65, n.5, p.783-794, 2011.
HAWERROTH, F.J.; HERTER, G.F.; PETRI, J.L.; LEITE, G.B.; PEREIRA. J.F.M. Dormência em frutíferas de clima temperado. Pelotas: EMBRAPA Clima Temperado, 2010. 56 p. (Documentos, 310)

IPCC - Intergovernmental Panel on Climate Change. Climate change 2014: mitigation of climate change. Cambridge: Cambridge University Press, 2015. 161 p.

IONESCU, I.A.; MOLLER, B.L.; SÁNCHEZ-PÉREZ, R. Chemical control of flowering time. Journal of Experimental Botany, Oxford, v.68, n.3, p.369-382, 2017.

KRETZSCHMAR, A.A.; BRIGHENTI, L.M.; RUFATO, L.; PELIZZA, T.R.; SILVEIRA, F.N.; MIQUELUTTI, D.J.; FAORO, I.D. Chilling requirement for dormancy break bud in European pear. Acta Horticulturae, Hague, n.909, p.85-88, 2011.

LANG, G.A. EARLY, J.D.; MARTIN, G.C.; DARNELL, R.L. Endo-, para- and ecodormancy: physiological terminology and classification for dormancy research. Hortscience, Alexandria, v.22, n.3, p.371-178, 1987.

LEMPE, J.; PEIL, A.; FLACHOWSKY, H. Time-resolved analysis of candidate gene expression and ambiente temperature during bud dormancy in apple. Frontiers in Plant Science, Bern, v.12, n.1, p.1-12, 2022.

LONDO. J. P.; JOHNSON, L. M. Variation in the chilling requirement and budburst rate of wild Vitis species. Environmental and Experimental Botany, Oxford, v.106, n.1, p.138-147, 2014.

LLOYD, J. Y.; FIRTH, D. J. Effect of defoliation time on depth of dormancy and bloom time for low-chill peaches. HortScience, Alexandria, v.25, n.12, p.1575-1578, 1990.

LUEDELING, E.; BROWN, P. H. A global analysis of the comparability of winter chill models for fruit and nut trees. International Journal of Biometeorology, Lisse, v.55, n.3, p.411-421, 2011.

LUEDELING, E.; KUNZ, A.; BLANKE, M. M. Identification of chilling and heat requirements of cherry trees - a statistical approach. International Journal of Biometeorology, Heidelberg, v.57, n.1, p.679-689, 2013.

MALAGI, G. The comparison of dormancy dynamics in apple trees grown under temperate and mild winter climates imposes a renewal of classical approaches. Trees - Structure and Function, Springer Verlag, v.29, n.5, p.1365-1380, 2015. 
PETRI, J.L.; SEZERINO, A.A.; DE MARTIN, M.S.; PEREIRA, E.S. Monitoramento do frio. Caçador: Epagri, 2019. 3p. (Informe Técnico, 005).

PETRI, J.L.; SEZERINO, A.A.; HAWERROTH, F.J.; PALLADINI, L. A.; LEITE, G.B.; DE MARTIN, M.S. Dormência e indução à brotação de árvores frutíferas de clima temperado. Florianópolis: Epagri, 2021, 153p. (Boletim Técnico, 192).

PRASCH, C.M.; SONNEWALD, U. Signaling events in plants: Stress factors in combination change the picture. Environmental and Experimental Botany, Oxford, v.114, n.1, p.4-14, 2015.

R DEVELOPMENT CORE TEAM. R: A language and environment for statistical computing. Vienna: $\mathrm{R}$ Foundation for Statistical Computing, 2022.

RAMEGOWDA, V.; SENTHIL-KUMAR, M. The interactive effects of simultaneous biotic and abiotic stresses on plants: mechanistic understanding from drought and pathogen combination. Journal of Plant Physiology, Amsterdam, v.176, n.1, p.47-54, 2015.

RICHARDSON, E.A; SEELEY, S.D; WALKER, D.R. A model for estimating the completion of rest for 'Redhaven' and 'Elberta' peach trees. HortScience, Alexandria, v.9, n.4, p.331-332, 1974.
RUTTINK, T.; AREND, M.; MORREEL. K.; STORME, V.; ROMBAUTS, S.; FROMM, J.; BHALERAO, R.P.; BOERJAN, W.; ROHDE, A. A molecular timetable for apical bud formation and dormancy induction in poplar. The Plant Cell, Rockville, v.19, n.8, p.2370-2390, 2007.

SETTIMI, L.; DAVANZO, F.; FARAONI, MICELI, G.; RICHMOND, D.; CALVERT, G.M. Update: hidrogen cyanamide-related Ilnesses-Italy, 2002-2004. Morbidity and Mortality Weekly Report, Atlanta, v.54, n.16, p.405408, 2005.

SHALTOUT, A.D; UNRATH, C.R. Rest completion prediction model for 'Starkrimson Delicious' apples. Journal of the American Society for Horticultural Science, Alexandria, v.108, n.6, p.957 961, 1983.

WEINBERGER, J.H. Chilling requirements of peach varieties. Proceedings of the American Society for Horticultural Science, Mount Vernon, v.56, n.1, p.122$128,1950$. 